\title{
EFEKTIVITAS EKTRAK DAUN BUNI (Antidesma Bunius L) TERHADAP PERTUMBUHAN BAKTERI Salmonella typhi
}

\author{
Sabariah *, Herlinawati ** \\ Fakultas Kedokteran Universitas Islam Al-Azhar \\ Jl. Unizar No.20 Turida Mataram \\ Email : hussabariah@yahoo.co.id
}

\begin{abstract}
ABSTRAK
NTB merupakan daerah yang kaya akan tanaman lokal yang bisa dimanfaatkan untuk obat herbal, salah satunya adalah tanman buni. Penelitian ini dilakukan secara Eksperimental murni untuk mengetahui adanya daya hambat ekstrak etanol daun buni (Antidesma bunius L) terhadap pertumbuhan Salmonella typhi Ekstrak etanol $70 \%$ daun buni (Antisdema bunius L) dengan konsentrasi $(5 \%=13 \mathrm{~mm}),(10 \%=14 \mathrm{~mm}),(20 \%=15 \mathrm{~mm})$ dan $(40 \%=17 \mathrm{~mm})$.dengan nilai statistik $(5 \%=12,75), \quad(10 \%=14,25), \quad(20 \%=14,75), \quad(40 \%=17,25)$,memiliki daya hambat terhadap pertumbuhan bakteri Salmonella typhi dengan jumlah rata-rata $15 \mathrm{~mm}$, Sehingga ekstrak daun buni (Antisdema bunius L) memiliki perbedaan daya hambat yang dapat dilihat dari jumlah nilai ratarata sebanyak $15 \mathrm{~mm}$.
\end{abstract}

Keyword: Daun buni, Salmonella typhi, Klorampenicol, infeksi.

\section{PENDAHULUAN}

Indonesia merupakan negara berkembang yang memiliki angka mortalitas dan morbiditas penyakit infeksi di Dunia. Angka kejadian penyakit infeksi di Indonesia mencapai 25\% (Dwiprahastio, 2005) sehingga menjadi masalah kesehatan terbesar yang ada di masyarakat. Beberapa bakteri patogen yang menyebabkan infeksi penyakit pada manusia diantaranya adalah Salmonella thypimurium, Escherichia coli, Bacillus cereus, dan Staphylococcus aureus (Jawetz et al., 2014). Salah satunya infeksi bakteri yang sering ditemui adalah Salmonella. Salmonella tidak hanya terjadi di negara berkembang

Jurnal Kedokteran

Vol. 06 No. 01 Desember 2020 akan tetapi terjadi juga di negara maju. Infeksi terjadi pada saluran cerna dan terkadang menyebar lewat peredaran darah ke saluran organ tubuh. merupakan bakteri gram -negative, tidak bersepora, tidak bersimpai, tampa fimbria dan berflagel peritrik, tumbuh pada suasana aerob dan anaerob fakultatif. (Raji, 2018). Infeksi yang disebabkan oleh Salmonella adalah demam, diare,kram perut, pusing, sakit kepala dan mual. (Radji, 2014). selain itu, tingkat virulensi mikroorganisme patogen juga semakin ganas. Penggunaan zat-zat antibiotika yang tidak sesuai dengan dosis yang telah ditentukan juga menjadi salah satu masalah resistensi bakteri sehingga 
menyebabkan kebalnya bakteri terhadap antibiotika yang sudah umum digunakan. Antibiotik merupakan obat yang dapat digunakan untuk membunuh atau menghambat pertumbuhan bakteri penyebab infeksi. Penggunaan antibiotik yang berlebihan dan tidak terkontrol menyebabkan bakteri resisten terhadap antibiotik tersebut (Jawetz et al., 2005). NTB merupakan daerah yang mayoritas penduduknya dihuni oleh masyarakat suku sasak sebagai masyarakan asli daerah. Di pulau ini terdapat beberapa tumbuhan local yang dahulunya sering di manfaatkan oleh masyarakat sebagai pangan alternative. Menurut (Rohayani et al. 2014,) 64 jenis tumbuhan local yang biasanya di manfaatkan yaitu bagian buah sebanyak 27 , biji sebanyak 15 jenis, batang sebanyak 2 jenis, umbi dan daun sebanyak 10 jenis. Salah satu tumbuhan yang bermanfaat untuk pengobatan tradisioal adalah daun buni (Atidesma bunius). Menurut beberapa penelitian tumbuhan genus Antidesma menunjukkan adanya aktivitas antibakteri diantaranya adalah Antidesma madagascariensis (Narod et al., 2004), Antidesma ghaesembilla pada konsentrasi $400 \mu \mathrm{g} /$ disk sampai 1200 $\mu \mathrm{g} /$ disk dengan zona hambat rata-rata 0 $16 \mathrm{~mm}$ (Habib et al., 2011), dan Antidesma venosum memiliki aktivitas antibakteri dalam mengobati infeksi seperti diare dan disentri amuba (Tor-

Jurnal Kedokteran

Vol. 06 No. 01 Desember 2020
Anyiin, \& Yakumbur, 2012). Antidesma bunius L Spreng yang berasal dari genus yang sama memungkinkan untuk memiliki aktivitas antibakteri. Berdasarkan beberapa penelitian tersebut peneliti merasa perlu untuk melakukan penelitian tentang efektivitas antibakteri untuk mengetahui potensi dari tanaman Antidesma bunius $L$ sebagai antibakteri.

\section{METODE PENELITIAN}

Jenis penelitian yang akan dilakukan adalah eksperimen murni yaitu untuk meneliti kemungkinan adanya hubungan sebab akibat diantra variable-variabel dengan cara menghadapkan klompok eksperimental pada beberapa macam kondisi perlakuan dan membandingkan akibat dengan satu atau lebih kelompok control yang tidak kenai perlakuan (Azwar, 2005). Rancangan yang dilakukan dalam penelitian ini adalah Rancangan Acak Lengkap ( RAL ) dengan 6 kelompok yang terdiri dari konsentrasi $5 \%, 10 \%$, $20 \%, 40 \%$ dan 2 kelompok kontrol terdiri dari kontrol positif dengan menggunakan kloramfenikol dan kontrol negatif menggunakan aquades.

\section{HASIL DAN PEMBAHASAN}

\section{Hasil Penelitian}

Hasil pengukuran diameter zona hambat ekstrak daun buni (Antidesma bunius L) 
terhadap pertumbuhan bakteri Salmonella typhi

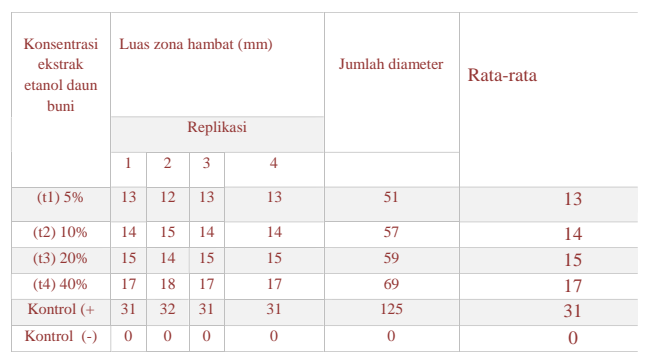

Berdasarkan pada table 1 diketahui bahwa ekstrak etanol $70 \%$ daun (Antisdema bunius L) dengan konsentrasi 5\%, 10\%, 20\% dan 40\% memiliki daya hambat terhadap pertumbuhan bakteri Salmonella typhi yang ditunjukan dengan adanya zona bening di sekitar media sumuran MHA dengan jumlah rata-rata pada ekstrak daun buni sebanyak $15 \mathrm{~mm}$. Zona hambat yang terbentuk pada kontrol negatif yang diberikan aquadest adalah 0 $\mathrm{mm}$ dan pada kontrol positif antibiotik koloramfenikol dengan rata-rata 317 $\mathrm{mm}$.

Berdasarkan tabel diatas nilai rata-rata zona hambat tertinggi adalah $17 \mathrm{~mm}$ dan $15 \mathrm{~mm}$ jika dibandingkan dengan kontrol positif nilai rata-rata yang didapat sebesar $31 \mathrm{~mm}$, hal tersebut dikatakan memiliki perbedaan sangat tinggi.Perbedaan besarnya zona hambat yang terbentuk pada masingmasing konsentrasi dapat diakibatkan karena adanya perbedaan besar kecilnya konsentrasi atau banyak sedikitnya kandungan zat aktif antibakteri yang terkandung di dalamnya serta kecepatan difusi bahan antibakteri ke dalam medium agar.

Faktor-faktor lain yang juga dianggap dapat mempengaruhi terbentuknya zona hambat adalah kepekaan pertumbuhan antibakteri, reaksi antara bahan aktif dengan medium dan temperatur inkubasi. Terbentuknya zona bening merupakan bentuk penghambatan pertumbuhan terhadap bakteri uji $B$. cereus dan Salmonella Indrawati et.al 2017).

Faktor lain yang dapat mempengaruhi perbedaan jauh antara kelompok eksperimen dengan kontrol karna konsentrasi yang digunakan terbilang rendah perlu adanya penambahan tingkat konsentrasi sehingga mendekati kelompok kontrol.

Efektifitas daya hambat antibiotik sintetis lebih kuat dibandingkan dengan antibiotik alami, namun efek samping yang ditimbulkan dari bahan sintetis sangan besar sehingga pada masa ini dengan sebutan back to natural banyak yang beralih ke bahan alam/tradisional dengan alasan lebih aman.

Pada penelitian ini terdapat nilai zona hambat dari konsentrasi terendah dari daun (Antidesma bunius L) dan mulai meningkat disetiap konsentrasi yang artinya ekstrak etanol $70 \%$ daun dan kulit batang buni (Antidesma bunius L) memiliki kemampuan daya hambat 
terhadap pertumbuhan bakteri Salmonella typhi.

\section{Uji homogenitas dan uji normalitas}

Hasil uji homogenitas data menggunaka levene.

\begin{tabular}{lll}
\hline & Levene & $\mathrm{P}$ \\
\hline Ekstrak daun & 1.800 & 0,164 \\
\hline
\end{tabular}

Pada tabel diatas ekstrak daun dengan nilai $\mathrm{P}(0,164)>0,05$ maka dapat dikatakan bahwa variansi sebaran data diatas adalah homogen.

\section{Hasil uji normalitas data}

menggunakan kolmogorov-smirnov

\begin{tabular}{lcc}
\hline & N & P \\
\hline Ekstrak daun & 4 & $\mathbf{0 , 2 4 6}$ \\
\hline
\end{tabular}

Pada tabel diatas diperoleh hasil pada daun $\mathrm{P}(0,246)>0,05$ maka dapat dikatakan bahwa data yang diperoleh berdistribusi normal.

\section{Uji Anova}

Pada penelitian ini dilakukan uji anova untuk mengetahui apakah terdapat perbedaan signifikan masing-masing Kelompok perlakuan konsentrasi 5\%, $10 \%, 20 \%, 40 \%$.

\section{Hasil uji anova}

\begin{tabular}{lcc}
\hline & Mean square & $\mathrm{P}$ \\
\hline Ekstrak daun & 0,208 & 0,000 \\
\hline
\end{tabular}

\section{Uji tukey HSD}

Daun buni (Antisdema bunius L) tukey HSD pemberian ekstrak daun Antidesma bunius L) untuk mengetahui perbedaan signifikan pemberian ekstrak tiap konsentrasi menggunakan uji lanjut HSD.

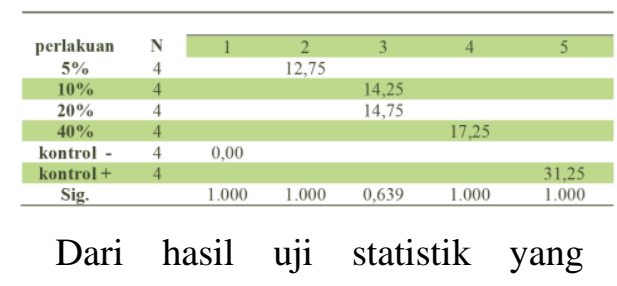
dilakukan dapat dilihat terdapat perbedaan nilai signifikan dari setiap konsentrasi.Hal ini menunjukan bahwa masing-masing konsentrasi tersebut mempunyai pengaruh yang berbeda nyata terhadap zona hambat terhadap bakteri Salmonella typhi. Sedangkan pada konsentrasi dengan hasil pada kolom yang sama, hal ini menandakan bahwa kedua konsentrasi tersebut tidak memberikan pengaruh yang berbeda nyata. Didapatkan nilai ekstrak tertinggi pada konsentrasi $40 \%$ dari ekstrak daun buni (Antidesma bunius L) dengan hasil 17,25 dan hasil terendah pada konsentrasi 5\% sebanyak 12,75.

Pada penelitian ini, terdapat adanya peningkatan luas zona hambat setelah konsentrasi ekstrak ditingkatkan. Seperti yang ditunjukan oleh grafik peningkatan pada ekstrak daun buni dan kulit batang buni (Antidesma bunius L) dibawah ini : 


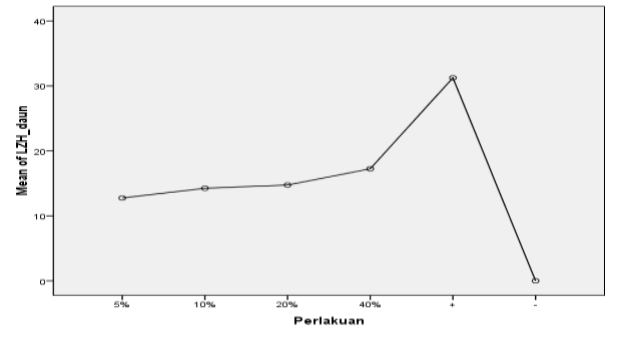

\section{Pembahasan}

Perbedaan nilai rendemen menurut Azwanida (2015) dipengaruhi oleh jenis pelarut, rasio pelarut terhadap sampel, ukuran partikel sampel, waktu ekstraksi dan suhu ekstraksi, semakin kecil ukuran partikel sampel maka akan meningkatkan luas permukaan antara sampel dan pelarut untuk terekstrak sempurna, sehingga akan mempengaruhi nilai rendemen (Puspita, 2019).

Ekstrak daun dan kulit batang buni (Antidesma bunius L) pada penelitian ini dibuat menjadi 6 kelompok, dengan uraian 4 kelompok konsentrasi yaitu 5\%, 10\%, 20\%, dan 40\%, 2 kelompok kontrol yaitu kontrol positif menggunakan kloramfenikol dan kontrol negatif aquades.

Ekstrak daun dan kulit batang buni (Antidesma bunius L) dengan konsentrasi 5\%, 10\%, 20\%, dan $40 \%$ terhadap pertumbuhan bakteri Salmonella Typi memiliki daya hambat. Diameter zona hambat yang terbentuk dengan rata-rata pada ekstrak daun buni (Antidesma bunius L) $13 \mathrm{~mm}, 14 \mathrm{~mm}$, $15 \mathrm{~mm}, 17 \mathrm{~mm}$ dan pada ekstrak kulit batang buni (Antidesma bunius L) Jurnal Kedokteran Vol. 06 No. 01 Desember 2020 diameter zona hambat rata-rata yang terbentuk $12 \mathrm{~mm}, 14 \mathrm{~mm}, 15 \mathrm{~mm}, 15$ mm. Aquades sebagai kontrol negatif tidak memiliki daya hambat dengan ditunjukan tidak adanya zona bening dengan diameter $0 \mathrm{~mm}$. pada kontrol positif yang menggunakan kloramfenikol memiliki zona hambat dengan rata-rata $31 \mathrm{~mm}$.

Pelarut etanol mempunyai titik didih yang rendah dan cenderung aman.Etanol juga tidak beracun dan berbahaya, selain itu etanol juga mempunyai kepolaran tinggi sehingga mudah untuk melarutkan senyawa resin, lemak, minyak, asam lemak, karbohidrat dan senyawa organik lainnya (Munawarah et.al 2010).Semakin tinggi konsentrasi etanol maka semakin rendah tingkat kepolaran pelarutnya (Shadmani et.al, 2004).

Menurut Nazri et.al, (2011) suatu zat aktif dikatakan memiliki potensi yang tinggi sebagai antibakteri jika pada konsentrasi rendah mempunyai daya hambat yang besar. Kriteria kekuatan antibakteri adalah sebagai berikut:

a) Diameter zona hambat $15-20$ $\mathrm{mm}$ : Daya hambat kuat

b) Diameter zona hambat 10-14 mm: Daya hambat sedang

c) Diameter zona hambat $0-9 \mathrm{~mm}$ : Daya hambat lemah

Diameter zona hambat bakteri dipengaruhi oleh konsentrasi ekstrak 
daun dan kulit batang buni (Antidesma

bunius L) yang didapat dari pengenceran.Pengukuran zona hambat antibakteri dapat dilihat dengan terbentuknya zona bening.Aquades digunakan sebagai kontrol negatif yang digunakan sebagai pembanding yang tidak memiliki aktivitas antibakteri terhadap Salmonella typhi.

Pada uji antibakteri ekstrak daun dan kuli batang buni (Antidesma bunius L) terhadap bakteri uji Salmonella typhi, dapat diketahui bahwa dari setiap konsentrasi pengenceran baik pada ulangan pertama, kedua, ketiga sampai keempat menghasilkan zona hambat dengan berbanding lurus.

Semakin besar konsentrasi ekstrak Antidesma bunius L semakin besar pula zona hambat yang dihasilkan. Diameter zona hambat terbesar dihasilkan oleh ekstrak daun buni dengan konsentrasi $40 \%$ sebanyak 17,25 mm.

Menurut Jawetz et.al, (2005) dalam Purnama (2013), perbedaan struktur dinding sel bakteri menentukan ikatan, penetrasi, dan aktivitas senyawa antibakteri.Bakteri gram positif pada dinding selnya memiliki lebih banyak peptidoglikan dan polisakarida (asam teikoat) serta sedikit lipid dibandingkan bakteri gram negatif. Polisakarida pada dinding sel Gram positif merupakan polimer yang polar dan berfungsi sebagai transport ion positif, sehingga dinding sel bakteri bersifat relatif polar, komponen membran plasma terdiri dari sekitar 30\% atau lebih dari berat sel ( Suhendra et.al, 2019).

Bakteri gram negatif lebih banyak mengandung lipid, sedikit peptidoglikan, membran luar berupa bilayer (berfungsi sebagai pertahanan selektif senyawa-senyawa yang keluar atau masuk sel dan menyebabkan efek toksik).Lapisan tengah yang merupakan dinding sel atau lapisan murein, dan membran plasma dalam. Membran luar mengandung fosfolipid, lipopolisakarida, dan lipoprotein yang jumlahnya sangat banyak. Membran luar tersedia sebagai organel aktif secara fisiologik, yang membentuk suatu barrier untuk senyawa hidrofilik, berfungsi sebagai molekul penyaring untuk molekul larut air, terdapat tempat menempel untuk sel inang dan konjugasi bakteri, melindungi dari racun lingkungan, dan lisis peptidoglikan dinding sel (Indrawati et.al, 2017).

Jawet et.al (2005) Sel bakteri gram negatif lebih kompleks dibandingkan gram positif, perbedaan utama adalah adanya lapisan membran luar, yang menyelimuti peptidoglikan, kehadiran membran ini menyebabkan dinding sel bakteri gram negatif kaya akan lipida serta mampu melindungi dari pengaruh lingkungan dan lisis peptidoglikan dinding sel, sehingga 
bakteri golongan gram negatif lebih tahan terhadap lingkungan hipertonis dari pada bakteri gram positif (Indrawati et.al, 2017).

Senyawa yang terdapat dalam tanaman buni menurut Almaidah (2018) terdapat senyawa flavonoid, terpenoid, saponin dan tanin, yang dimana senyawa yang dapat menghambat antibakteri seperti penelitian yang dilakukan oleh Khanbabae et.al (2001) yang mempunyai aktivitas antiinflamasi, astringen, antidiare, diuretic dan antiseptik.

Tanin juga berpotensi sebagai senyawa antibakteri, tanin adalah senyawa polifenol yang dapat larut dalam air, gliserol, metanol, hidroalkoholik, propilena glikol tetapi tidak larut dalam benzena, kloroform, eter, petroleum eter dan karbondisulfida. menjelaskan Mekanisme penghambatan senyawa tanin sebagai antibakteri dengan cara bereaksi dengan membran sel, inaktivasi enzim-enzim esensial, dan destruksi atau inaktivasi fungsi material genetik (puspita, 2019).

Kloramfenikol berkeja dengan menghambat sintesis protein bakteri. Obat ini terikat pada ribosom subunit 50 s dan menghambat enzim peptidil transferasen sehingga ikatan peptide tidak terbentuk pada proses sintesis protein bakteri (Gunawan dkk, 2013).
Sintesis polipeptida pembentukan protein, untuk memulai sintesis protein ikatan hidrogen antara basa-basa DNA diputuskan secara enzimatis pada daerah tertentu, sehingga rantai tersebut akan terpisah. Urutan pendek dari DNA yang tidak berpasangan kemudian menjadi templat untuk transkripsi. Hanya satu rantai yang kemudian menjadi satu arah untuk transkripsi (Irianto, 2013)

Obat kloramfenikol juga efektif terhadap kebanyakan strain E. coli, $K$. pneumonia dan P. mirabilis, kebanyakan strain serratia, providensia dan proteus retgerii resisten, juga kebanyakan strain $P$. aeruginosa dan strain tertentu S. typhi (Gunawan et.al, 2013).

Ekstrak daun (Antisdema bunius L) memiliki perbedaan daya hambat yang dapat dilihat dari jumlah nilai ratarata pada daun buni sebanyak $15 \mathrm{~mm}$. Sehingga diperoleh zona hambat ekstrak daun dengan konsentrasi 5\%, 10\%, 20\% dan $40 \%$ dengan nilai rata-rata ekstrak daun (13 mm, $14 \mathrm{~mm}, 15 \mathrm{~mm}, 17 \mathrm{~mm}$ ) dengan nilai statistik $(5 \%=12,75)$, $(10 \%=14,25)$, $(20 \%=14,75)$, $(40 \%=17,25)$.

\section{SARAN}

Perlu dilakukan penelitian lain mengenai khasiat dan kegunaan tumbuhan buni, dilakukan penyarian ektrak dengan metode dan pelarut yang 
berbeda. Serta menggunakan bakteri yang berbeda untuk penelitian selanjutnya

\section{DAFTAR PUSTAKA}

Almaidah M. F., 2018, Uji Aktivitas Anti Inflamasi Ekstrak Etanol Daun Buni (Antidesma bunius L. Spreng) Terhadap Tikus Putih (Rattus

Norvegicus) [Skripsi]Fakultas Kedokteran Dan Ilmu Kesehatan Uin Alauddin Makassar.

Dwiyanto K., Wina E., Priyanti A., Natalia L., Herawati T., Purwandaya B., 2008, Pola kepekaan enterobacter sakazaki terhadap antibiotic

Gunawan S. G., Nafrialdi R. S., Elysabeth, 2013, Farmakologi Dan Terapi, Departemen Farmakologi Dan Terapeutik FK.UI, Jakarta.

Indawati, I., dan Rizki, A.F.M., 2017, Potensi Ekstrak Buah Buni (Antidesma bunius L) sebagai Antibakteri dengan Bakteri Uji Salmonella thypimurium dan Bacillus cereus.[Skripsi] Departemen Biologi Fakultas Matematika dan Ilmu Pengetahuan Alam Universitas Padjadjaran.

Irianto K., 2013, Mikrobiologi Medis, ALFABETA, Bandung

Jawetz, M., dan Adelberg, 2005, Mikrobiologi Kedokteran, Edisi 23, Alih Bahasa Huriwati Hartanto dkk, Buku Kedokteran ECG, Jakarta.

Jawetz, M., Adelbreng, 2013, Mikrobiologi Kedoktern, Edisi 25, Salemba Medika, Jakarta.

Khanbabaee, K., Ree, T.V., 2001, Tannins Classification and Defenition, Nat Prod Rep.

Munawarah, S. dan Handayani, P.A., 2010, Ekstraksi Minyak Daun Jeruk Purut (Cytrus hydtrik D.C) Dengan Pelarut Etanol dan $\mathrm{N}$ -
Heksan. Jurnal Kompetensi Teknik.

Suhendra C.P., Widarta I.W.R., Wiadnyani A.A.I.S., 2019, pengaruh konsentrasi etanol terhadap aktivitas antioksidan ekstrak rimpang ilalang (imperata cylindrica (l) beauv.) pada ekstraksi menggunakan gelombang ultrasonic, Fakultas Teknologi Pertanian, Universitas Udayana, Bali.

Puspit P.J.,2019, Aktivitas Antibakteri Ekstrak Daun Sirih Merah, Department of Biochemistry, Bogor Agricultural University.

Purnama, W. B., 2013, Aktivitas Antibakteri Glukosa Terhadap Staphylococcus aureus, Pseudomonas aeruginosa, Bacillus subtilis dan Escherichia coli, Fakultas Farmasi, Universitas Muhamadiyah Surakarta.

Rohyani, I.S., Aryanti, E., Suripto. 2015. Potensi Nilai Gizi Tumbuhan Lokal Pulau Lombok Sebagai Basis Penguatan Ketahanan Pangan Nasional.Prom Sem Nas Masy Biodiv Indon. Vol. 1. No 7 (hal) 1698-1701.

Shadmani, A., I. Azhar, F. Mazhar, M.M. Hassan, S.W. Ahmed, I. Ahmad, K. Usmanghani dan S. Shamim. 2004. Kinetic studies on Zingiber offcinale. Journal of Pharmaceutical Sciences.

Soetan K. O., Oyekunie M.A., Aiyelaagbe $\mathrm{O} . \mathrm{O}$ and Fafunso M.A. Evaluation of The Antimicrobial activity of Saponins Extract of Sorghum bicolor Moench.African Journal of Biotechnology.

Nijveldt. R, J., dkk. 2001, Flavonoids; a Review of Probable Mechanisms of Action and Potential Applications.American Journal of Clinical and Nutrition Vol 74. America. 